\title{
A Study for the Germination of Allaya-vijñana Thought:
} From the Perspective of Karmasiddhi-prakarana

\section{HiBI Yuka}

\section{Introduction}

The question "how did alaya-vijñāna thought become?" has already yielded vast theories in previous studies. In this paper, I will summarize these studies and point out some problems.

\section{The Previous Studies of the Germination of Alaya-vijñāna Thought}

Asanga taught gongneng 功能 instead of zuoyong 作用 in order to explain bijja which indicates the mind of individuals (ālaya-vijñāna) in Mahāyāna-samgraha. Afterwards, Vasubandhu taught that "twelve nidānas depend on a consciousness" in Ärya-daśabhūmivyākhyāna (Sakamoto 1981: 252). From this method, it would correct the thought of "emptiness" branched from śūnyatā thought of Mādhyamika. Therefore, the thought which denies all works between whole things became precarious. It seems this is one of the way that the sect of Yogācāra brings there opinion to more physical and common way of thought.

Sarvāstivāda taught the reality of the past karma, the theory which supports "real existence" and a arambhavāda's standpoint. On the other hand, Sautrāntika taught the conceptualism and parināmavāda theory. After these sects became common, Nāgārjuna denied the "real existence" of both sense organs and sense objects. ${ }^{1}$ )

As a result, Sarvāstivāda interpreted pratyaya based on kriyā while Mādhyamika denied them on the logic of the doctrine of the emptiness. ${ }^{2)}$ Thereafter, Asanga created the thought of bìja and àlaya-vijūāna.

\section{When Did Vasubandhu Change His View?}

According to Kusumoto (2007: 11), it was not a gradual change but he already had three standpoints when Vasubandhu wrote $A K B h$ : Sarvāstivāda, Sautrāntika and Yogācāra. 
Kritzer (2005), Harada (1996; 1997; 1998), Park (2007) clarified that Yogācārabhūmi had also directly influenced the Sautrāntika theory in $A K B h$. For example, there was an expression such as "the bija of virtue has not burned" in the chapter of Indriya in $A K B h^{3)}$ which may indicate the tathāgata-garbha thought of Mahāyāna Buddhism. Thus, it is said that Vasubandhu already stood on Mahāyāna's point of view when he wrote $A K B h$.

Lammote (1936) insisted Vasubandhu still stood on the Sautrāntika's point of view although his thought was close to Yogācāra sects indeed. On the other hand, Lee (2001) argued that Vasubandhu strongly had the Sautrāntika's viewpoint when he was writing $A K B h$ and he changed his opinion to Yogācāra in the writing Vyākhyāayukti. Moreover, Satō (1978: 18) evaluated the Vasubandhu's standpoint that taught the reality of outside of our mind and objective reality in $K S$ of Sautrāntika. It seems to be a relevant material to confirm the transformation from Abhidharma of Hīnayāna Sarvāstivāda to Mahāyāna Yogācāra thoughts.

According to Schmithausen (1987), Vimśatikā-vijñaptimātratā-siddhi (Vimś) insists that there exists only a vijñaptimātratāa (i.e., vijñapti) in this world. That is to say, nothing would exist expect this kind of consciousness. This view point is clearly stands on the Yogācāra's point of view. However, ălaya-vijñāna theory did not appear in Vimś, he said. Thus, the thought of vijñaptimātratā appeared, even though there preached the "real existence" of rūpa in $K S$. Hence, it is difficult to classify $K S$ to the vijñaptimātrata $\bar{a}$ thought but the vijñaptimātrata thought in $K S$ meant only to solve the question of a body of samsāra, which remained immature theory in $A K B h$.

\section{Comparison of the Origin of the Transmigration in $A K B h$ and $K S$}

Considering about consciousness, the question "what are its characteristics?" may also arouse our curiosity. In the pre-Buddhist religion in ancient India, they believed that the existence of primordial materiality, which is apart from our body (āśraya). As an example, the early Sāmkhya theory of primordial materiality (prakrti), which describes the origins of the cosmos and life within it as an expression of an underlying absolute substratum, influenced Vasubandhu's "parināmavāda" theory (Yokoyama 1982: 119; Katō 2012: 134); Moreover, Sautrāntika bijja theory supported "real existence" and "parin̄āmavāda."

On the other hand, Sarvāstivāda taught the phalam pratigrhitāạm, phalam prayacchati theory of past and present karma to explain about the transmigration caused by hetu-phalam 
of karma. ${ }^{4)}$ Against this theory, Sautrāntika and Yogācāra sects strictly constructed ksananirodha thoughts and denied the "real existence" of the past and the future. They brought the teaching of bija, samtati-parināma-viśeșa and the conception of ălaya-vijñāna.

Furthermore, the sects of Kăsyapiya insisted that the result which became present had destroyed at that moment and corrected the interpretation of Sarvāstivāda in Da piposha lun 大毘婆沙論. The question “does the past karma also remain after reaching nirvāna?" still remains.

Considering this problem, Vasubandhu suggested the alaya-vijñanna thought. The term of ălaya-vijñāna did not appear in $A K B h$ but in $K S .{ }^{5)}$ However, Lamotte and Yamaguchi insisted that Vasubandhu taught his theory based on the Sautrāntika's standpoint because they confirmed the "real existence" of rūpa. The pioneering thoughts of älaya-vijñāna or vipāka-vijñāna is nothing but bijja and santati-parināma-viśeșa thought in $A K B h$.

In Da piposha lun, bija indicates nothing but the example of "germinate of the seeds," a metaphor for the phenomenon of cause and effect. The bija theory in $A K B h$, however, indicates the nāma-rūpa, which have the function of the "work," "6) and made of pañca-skandha.

As stated above, although there were some theories that Vasubandhu were to be stand on Sautrāntika's viewpoint in $A K B h$ and $K S$, it became clearer that there was a distinctly difference of the insistence of the identity of samtäna in $A K B h$ and $K S$. In $K S$, it is defined to be the vijñanna while vijñaptimātratā thought had not germinated yet, which means it has not been more than "vijñāna of a monolayer" thought of Sautrāntika. Therefore, $K S$ taught nothing but a vipāka-vijñāna, that gathers the subjects of samtati-parin̄ama-viśeșa or a kind of bija.

\section{Concluding Remarks}

The outline of the germination of ălaya-vijñāna, became clearer beyond previous studies as the following. First of all, the conception of parināma originated from Sāmkhya which had brought into Buddhism by Sarvāstivāda as "samtati-parināma-viśeșa." Then, Vasubandhu had turn into "parin̄āmavāda" theory. In this process, Samdhi-nirmocana-sūtra taught that the Mādhyamika's emptiness thought influenced the development of alayavijñāna thought. ${ }^{7)}$

Regarding the descriptions about bija in $A K B h$ and $K S$, it became clearer why did Vasubandhu, who stood on Sautrāntuka's "samtati-parināma-viśesa" theory, changed his view 
for Yogācāra's “ālaya-vijñāna” theory.

As a result, the nāma-rūpa (bijja), which has kriyā of making result, is made of pañcaskandha and has the similar definition with "vipāka-hetu" and "vipäka-phala" at the point of the character of "samtati-parinama-viśeșa." It was clear to consider these thoughts have a common definition. Furthermore, the teaching of the "real existence" of the past karma, either the karma which had already made a result or not, might be the teaching on the basis of samsāra (rebirth of karma) thought within Sarvāstivāda.

However, these vipāka-hetu, phalam pratigrhitāạ or bija is not the only one thing for one body of samsāara. In $A K B h$, it is taught that one samsāra has numerous bijja. Vasubandhu challenged to summarize these bijja theories to one ayyatana. This is the beginning of alaya-vijñāna of Vasubandhu. So, the question of a body of samsāra explained with past karma in $A K B h$ and ālaya-vijñāna in $K S$.

The biggest difference between the teaching of $A K B h$ and $K S$ was a definition of where to define a body of samsāra itself. $K S$ stressed the answer in älaya-vijñana which was what Vasubandhu wanted to insist the most. Moreover, $A K B h$ and $K S$, written in the Sautrāntika's stand point, emphasized the necessity of identification of individuals, so there was an establishment of bijja, prāpti and vipāka-vijūāana.

\section{Notes:}

1) Mūlamadhyamakakārikāh (MMK) Cakṣurādīndriyaparīkṣā Chapter 6g.

2) $M M K \mathrm{Kar}-$ makārakaparīkșā Chapter $2 \mathrm{~g}$.

3 ) $A K B h$ pp.63-64; $A K V$ p. 147.

4) $A K B h$ p.97; $A K V$ p.230.

5 ) $K S$ pp.164-165.

6) $A K V$ pp. 147-148.

7 ) Only to harmonize the six-vijñanas, the vipāka-vijñāna was stood there. According to Samdhi-nirmocana-sütra, the teaching of Prajñ̄a-pāramitā, which became the base of Nāgārjuna's thought lately, denied the view that stuck on the thought of "Absolute existence" of Abhidharma Buddhism. However, in order to indicate the characteristics of $a$-svabhāva of whole things (śūnyatā), people became to stuck on the siunyatā thought. It was an excesive interpretation. Afterwards, it became necessary to sublate these two attachments of "Absolute existence" and "śūnyatā," the "vijñaptimātratā" thought had occurred. (Cf. Kudō 1982)

\section{Abbreviations:}

AKBh Abhidharmakośabhāṣya of Vasubandhu. Ed. P. Pradhan. Tibetan Sanskrit Works Series, vol. VIII. Patna: K. P. Jayaswal Research Institute, 1967.

AKV Sphutārthā Abhidharmakośavyākhyā: The Work of Yaśomitra. Ed. U. Wogihara. Tokyo: Sankibo Buddhist Book Store, 1971. 
KS Karmasiddhi-prakarana (Las grub-pahi rab-tu-byed-pa). Der, No. 4062. A Complete Catalogue of The Tibetan Buddhist Canons. Published by Tōhoku Imperial University.

\section{References:}

Harada Wasō 原田和宗. 1996. “'Kyōryōbu no ‘tansō no' shiki no nagare’ to iu gainen e no gimon (1)” 〈経量部の「単層の」識の流れ〉という概念への疑問 (1). Indogaku Chibettogaku kenkyū イ ンド学チベット学研究 1:134-193.

1997. “'Kyōryōbu no 'tansō no' shiki no nagare’ to iu gainen e no gimon (2)"〈経量部の「単 層の」識の流れ〉という概念への疑問 (2). Indogaku Chibettogaku kenkyū インド学チベッ 卜学研究 2:22-59.

—. 1998. “'Kyōryōbu no 'tansō no' shiki no nagare’ to iu gainen e no gimon (3)”〈経量部の「単 層の」識の流れ〉という概念への疑問 (3). Indogaku Chibettogaku kenkyūインド学チベッ 卜学研究 3:92-110.

Katō Junshō 加藤純章. 2012. “Kusharon ni okeru 'sōzoku no tokushu na henka' (saṃtati-parināmaviśeșa sōzoku tenpen shabetsu): Shakujū-setsu kara tenpen-setsu e (oboegaki)"『俱舎論』にお ける「相続の特殊な変化」(samtati-parināma-viśseșa 相続転変差別): 積集説から転変説へ(覚 え書). Buzan gakuhō 豊山学報 55:136-122.

Kritzer, Robert. 2005. Vasubandhu and the Yogācārabhūmi: Yogācāra Elements in the Abhidharmakośabhāșya. Studia Philologica Buddhica, Monograph Series 18. Tokyo: International Institute for Buddhist Studies.

Kudō Shigeki 工藤成樹. 1982. “Chūgan to Yuishiki: Kū, Ichijō/Sanjō, Nitaisetsu o megutte” 中観と 唯識: 空,一乗 •三乗, 二諦説をめぐって. In Yuishiki shisō 唯識思想, Kōza Daijō Bukkyō 講 座大乗仏教 8. Tokyo: Shunjūsha.

Kusumoto Nobumichi 楠本信道. 2007. Kusharon ni okeru Seshin no Engi-kan『俱舎論』における 世親の縁起観. Kyoto: Heirakuji Shoten.

Lamotte, E. 1936. "Le Traité de l'acte de Vasubandhu: Karmasiddhiprakarana." Mélanges chinois et bouddhiques 4:151-236.

Lee, Jong Cheol 李鐘徹. 2001. Seshin shisō no kenkyū: Shakkiron o chūshin to shite 世親思想の研 究:『釈軌論』を中心として. Tokyo: Sankibō Busshorin.

Park Changhwan. 2007. "The Sautrāntika Theory of Seeds (bija) Revisited." PhD diss., University of California.

Sakamoto Yukio 坂本幸男. 1981. Abidatsuma no kenkȳu 阿昆達磨の研究. Tokyo: Daitō Shuppansha. Satō Mitsuo 佐藤密雄. 1978. Daijō jōgōron 大乗成業論. Tokyo: Daitō Shuppansha.

Schmithausen, Lambert. 1987. Alayavijñāna: On the Origin and the Early Development of a Central Concept of Yogācāra Philosophy. Tokyo: International Institute for Buddhist Studies of the International College for Postgraduate Buddhist Studies.

Yokoyama Kōitsu 横山紘一. 1982. “Seshin no Shiki-tenpen”世親の識転変. In Yuishiki shisō 唯識 思想, Kōza Daijō Bukkyō 講座大乗仏教 8. Tokyo: Shunjūsha.

〈Key words〉 Karmasiddhi-prakarana, Abhidharmakośabhāṣya, consciousness, ālaya-vijñāna

(Graduate Student, Rissho University) 